\title{
STRATEGI PENETAPAN HARGA DALAM MENINGKATKAN PROFITABILITAS USAHA KONVEKSI KEMBANG MAS
}

\author{
Rodhiah $^{1,}$ Leo Colin ${ }^{2}$, Fadillah Akbar ${ }^{2}$, Raden Mas ${ }^{3}$ \\ ${ }^{1}$ Jurusan Manajemen Fakultas Ekonomi dan Bismis, Universitas Tarumanagara Jakarta \\ ${ }^{1,2,3}$ Mahasiswa Jurusan Manajemen Fakultas Ekonomi dan Bismis , Universitas Tarumanagara Jakarta \\ ${ }^{1}$ Email: rodhiah@fe.untar.ac.id
}

\begin{abstract}
Pricing strategy is the most important decision in marketing activities. Because it will have a direct impact on the acceptance of a company's opinion, the profit obtained is one source because of the price offered to consumers. The partner who is the place of activity is a business engaged in the embroidery convection which is located in West Jakarta. PKM activities are carried out by looking at the problems of SMEs, especially in terms of price strategies offered to consumers, plus there are quite a lot of border businesses around partners, so partners need to have the right price strategy in dealing with competitors and increasing profits. The method offered to training/socialization partners is in the form of a zoom meeting, which includes an introduction to pricing strategies, pricing goals, and steps to determine the selling price that partners should use. The results of the activities carried out run well, partners gain knowledge about pricing strategies, to increase their profits.
\end{abstract}

Keywords: pricing strategy, pricing steps, training, profit

\begin{abstract}
ABSTRAK
Strategi harga merupakan keputusan yang paling penting dalam kegiatan pemasaran karena akan berdampak secara langsung pada penerimaan pendapat suatu perusahan. Selanjutnya keuntungan yang diperoleh dapat menjadi salah satu sumber karena adanya harga yang ditawarkan ke konsumen. Mitra yang menjadi tempat kegiatan merupakan usaha yang bergerak di bidang konveksi bordir yang berlokasi di Jakarta Barat. Kegiatan PKM dilakukan dengan melihat permasalahan UKM terutama dalam hal strategi harga yang ditawarkan ke konsumen, ditambah lagi usaha bordir di sekitar mitra cukup banyak, sehingga mitra perlu memiliki strategi harga yang tepat dalam menghadapi pesaing dan meningkatkan keuntungan. Metode yang ditawarkan ke mitra pelatihan/sosialisasi secara online dalam bentuk zoom meeting. yang meliputi pengenalan tentang strategi harga, sasaran penetapan harga, dan langkah melakukan penetapan harga jual yang sebaiknya digunakan mitra. Hasil kegiatan yang dilakukan berjalan dengan lancar, mitra mendapatkan bekal pengetahuan tentang strategi harga, dalam upaya meningkatkan keuntungan .
\end{abstract}

Kata kunci: strategi harga, langkah penetapan harga, pelatihan, keuntungan

\section{PENDAHULUAN}

\section{Analisis situasi}

Strategi harga merupakan unsur dalam bauran pemasaran yang sangat penting, karena melalui harga suatu usaha akan mendapatkan keuntungan. Hub Pages, (2013); Julio (2011) Harga sangat penting dalam kelangsungan bisnis, jika harga tidak ditentukan dengan benar, dapat berdampak negatif pada produk dan profitabilitas perusahaan. Afsar (2019) menjelaskan bahwa Pentingnya penetapan harga yaitu harga mempunyai peran yang vital dalam terjadinya kesepakatan antara penjual dan pembeli dari produsen ke tangan konsumen maka dari itu dalam menetapkan harga yang lebih bijaksana." kembang mas perlu mengetahui penetapan harga yang baik berawal dari memahami segala nilai yang terdapat dalam suatu produk ataupun jasa. melakukan penetapan harga jual kepada konsumen menjadi kunci kesuksesan suatu usaha. Harga sangat memiliki efek pada posisi dan kinerja keuangan usaha dan persepsi pembeli, juga merupakan suatu tolak ukur untuk konsumen ketika konsumen mempunyai kesulitan didalam menilai suatu kualitas produk yang diinginkan oleh komsumen.

Witama Alex (2019) menjelaskan bahwa dari segi kualitas, harga. Sebagian besar konsumen mempertimbangkan aspek tersebut sebelum membeli suatu produk. Tidak berfokus hanya pada 
kualitas , melainkan konsumen juga mementingkan seberapa layak harga tersebut pada produk atau jasa.". Ketika produk yang diinginkan bagi konsumen ialah produk yang memiliki mutu atau kualitas yang baik, tentu harga yang harus dikeluarkan oleh produk tersebut akan mahal. Sebaliknya ketika produk tersebut kulaitasnya kurang, maka harga yang dikeluarkan untuk produk tersebut juga tidak akan tinggi. Furinto, Assan (2018) menjelaskan bahwa kualitas dari sebuah produk harus memenuhi keinginan konsumen karena konsumen telah mengeluarkan biaya dalam membeli produk tersebut.

Sejalan dengan masalah yang dimiliki oleh usaha kembang mas sebagai mitra kegiatan PKM yaitu tentang penentuan harga dalam meningkatkan keuntungan. Harga juga merupakan faktor penting dalam membangun hubungan jangka panjang dengan pelanggan dan teknik penetapan harga yang serampangan dapat membingungkan dan membuat pelanggan menjauh,dan akhirnya akan menurunkan keuntungan.

Afsar (2019) menjelaskan bahwa Pentingnya penetapan harga yaitu harga mempunyai peran yang vital dalam terjadinya kesepakatan antara penjual dan pembeli dari produsen ke tangan konsumen maka dari itu dalam menetapkan harga yang lebih bijaksana. Kembang mas perlu mengetahui penetapan harga yang baik berawal dari memahami segala nilai yang terdapat dalam suatu produk ataupun jasa. melakukan penetapan harga jual kepada konsumen menjadi kunci kesuksesan suatu usaha. Harga sangat memberikan efek pada posisi dan kinerja keuangan usaha dan harga memiliki pengaruh terhadap persepsi pembeli . harga juga merupakan suatu tolak ukur untuk konsumen ketika konsumen mempunyai kesulitan didalam menilai suatu kualitas produk yang diinginkan oleh komsumen.

Bisnis Usaha kecil dan menengah dari Kembang Mas adalah suatu usaha yang bergerak dalam bidang industri konveksi bordir . Pemilik usaha Kembang Mas bernama Leya Levina beralamat di Jl. jembatan dua Jakarta Barat. Berdiri sejak tahun 2018. Dengan adanya pengendalian kualitas, proses produksi dan produk jadi maka akan meminimal terjadinya produk cacat atau kerusakan produk mesin yang dibeli merupakan mesin bekas yang tahun dibuatnya mesin tersebut pada tahun 2009. meskipun mesin tersebut sudah sedikit tua, tetapi mesin tersebut masih dapat beroperasi dengan cukup baik dan dapat memenuhi permintaan.

Permasalahan utama pada usaha Kembang Mas yaitu strategi harga, karena harus disesuaikan dengan modal produksi jasa dan pesaing. Dari observasi awal menunjukkan adanya komplain konsumen dari harga yang ditawarkan. Jika dibandingkan dengan harga pesaing yang lebih murah. Sementara itu pemilik belum memiliki pengetahuan tentang strategi harga secara optimal dalam menjalankan usaha. Kondisi ini mempengaruhi pemilik untuk unggul dari pesaing.Untuk itu tujuan kegiatan PKM melakukan transfer pengetahuan tentang strategi harga guna meningkatkan pemahaman kepada mitra secara lebih optimal.

\section{METODE PELAKSANAAN PKM}

Tahapan pelaksanaan kegiatan meliputi: 1). Tahap persiapan, dalam tahap ini tim menghubungi mitra untuk melakukan kerja sama. Tim melakukan obsevsai awal yang menjadi prioritas masalah mitra untuk dipecahkan bersama. 2). Tahap pelaksanaan , pelakanaan kegiatan meliputi penyusunan materi kegiatan berupa PPT yang akan ditransfer ke mitra, berkoordinasi dengan pemilik menentukan tanggal pelaksanaan zoom meeting, melakukan pembagian tugas dengan mahasiswa yang membantu kegiatan, membuat link zoom meeting, 3). Pelaksana PKM menyampaikan materi sosialisasi melalui ceramah, diskusi, dan tanya jawab secara daring melalui zoom meeting yang dibantu oleh 2 mahasiswa dari jurusan manajemen. Ketua tim mejelaskan tentang strategi harga terkait keuntungan usaha, selanjutnya meminta mitra untuk bertanya jika belum di mengerti dari materi yang disampaikan. 4). Tahap hasil akhir, melakukan evalusi dan menyusun laporan kegiatan . 


\section{HASIL KEGIATAN DAN PEMBAHASAN}

\section{Profil mitra}

Bisnis Usaha Kecil dan menengah dari kembang mas didirikan pada tahun 2018 , didirikan oleh wirausaha muda bernama Leya levina. Awalnya, usaha ini hanya memiliki satu buah mesin dan 2 karyawan, produksi dilakukan di rumah sewaan. Berlokasi di Jalan Jembatan dua Blok B no 62 RT 10 RW 02 Jakarta Barat. Tahap permulaan dalam menjalankan bisnis kurang menguntungkan. Karena masih kurangnya konsumen dan penentuan harga yang masih banyak pertimbangan, harga yang ditawarkan ke konsumen sulit bersaing. Tidak dapat disesuaikan dengan kemauan konsumen. Selain itu mitra harus menutup modal yang telah dikeluarkan, membeli mesin, membayar gaji karyawan dan lainnya.

Namun seiring berjalannya waktu, usaha Kembang Mas semakin meningkat. Sekarang pada tahun 2021 usaha Kembang Mas telah mempunyai 2 buah jumlah mesin dan 4 karyawan, permintaan juga semakin meningkat. Kunci keberhasilan usaha Kembang mas itu ada pada proses pengendalian kualitas. Adanya pengawasan yang ketat mulai dari awal proses produksi sampai akhir produksi, telah mampu menjaga kualitas yang diinginkan atau ditetapkan oleh pemilik usaha. Melalui pengendalian kualitas tersebut, proses produksi dan produk jadi telah meminimalkan terjadinya produk cacat atau kerusakan produk. Apalagi mesin yang dibeli merupakan mesin bekas tahun 2009. Meskipun mesin tersebut sudah sedikit tua, tetapi mesin tersebut masih dapat beroperasi dengan cukup baik dan dapat memenuhi permintaan.

Pada masa pandemi COVID-19 ini tidak terlalu berdampak pada usaha Kembang mas karena jenis usaha konveksi dilakukan dirumah, tidak kena PSBB maupun PPKM. Usaha tetap dapat berproduksi, walaupun ada sedikit penurunan dalam pemesanan dari pelanggan. Permintaan produksi dari kembang mas ini biasanya berasal dari luar negeri yang kemudian hasil dari produksi tersebut di ekspor ke luar negeri.

Berikut ini mesin dan mesin contoh hasil produksi jasa bordir dari usaha kembang mas:
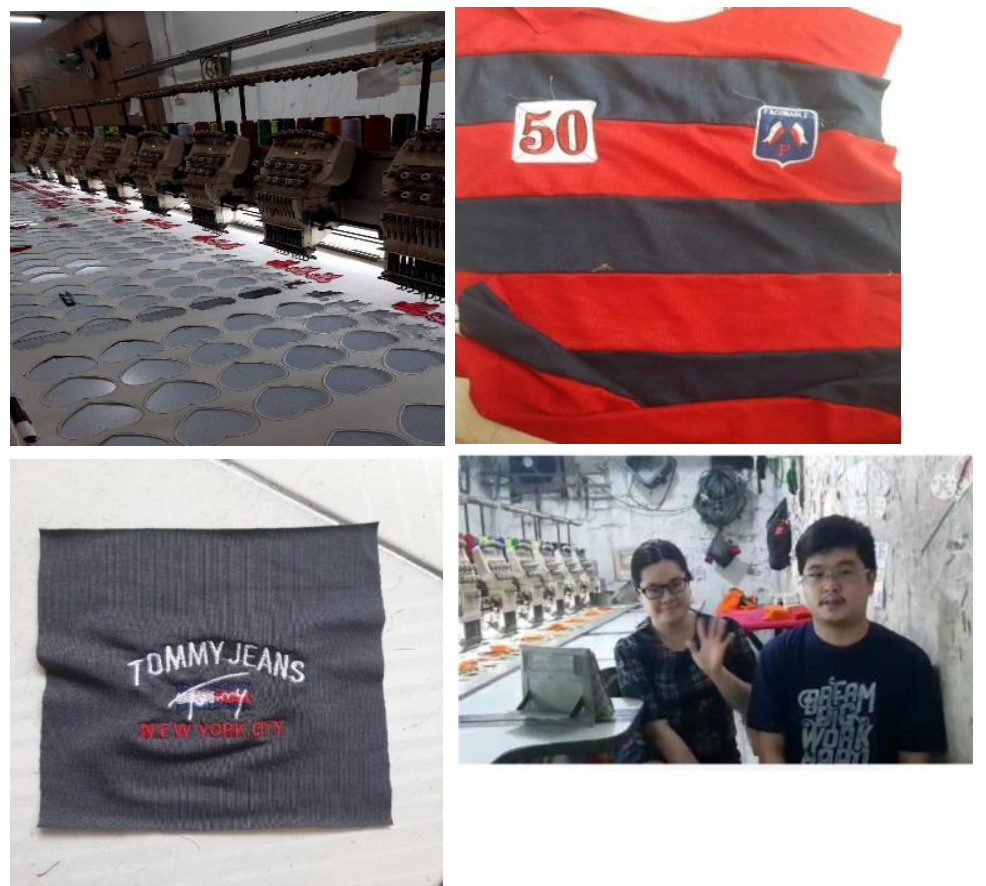

Gambar 1

Foto mesin bordir, produk dan mitra 


\section{Implementasi strategi harga dan sosialisasi secara daring}

Output yang dirancang dalam mengatasi masalah mitra adalah memperkenalkan strategi harga yang tepat dalam meningkatkan keuntungan pada produk yang dijual ke konsumen. Cara tercepat dan paling efektif bagi usaha untuk mewujudkan keuntungan maksimalnya adalah dengan menetapkan harga yang tepat. Harga yang tepat dapat meningkatkan keuntungan lebih cepat daripada peningkatan volume penjualan; Spesifikasi model diberikan pada kegiatan ini adalah: memperkenalkan tentang harga, persepsi harga, sasaran penetapan harga, langkah dalam penetapan harga. strategi penetapan harga yang baik harus mengarahkan inti organisasi perilaku, komunikasi serta profitabilitas (Meehan et al., 2011).

Kotler and Armstrong (2018) Harga merupakan sekumpulan uang yang dialokasikan bersumber dari sebuah jasa tersebut ataupun produk tersebut. atas jumlah dari nilai yang telah dikeluarkan oleh konsumen dan manfaat-manfaat yang diberikan pada saat menggunakan produk atau jasa tersebut." di sini telah dijelaskan bahwa harga merupakan sejumlah uang yang dibebankan atas sebuah produk atau jasa. Harga sebuah produk atau jasa merupakan sebuah penentu utama permintaan. selain itu harga akan merubah persepsi dimata konsumen. Konsumen mempunyai persepsi bahwa harga produk yang mahal memiliki kualitas produk yang baik, begitu sebaliknya harga produk yang murah memiliki kualitas produk yang buruk. Persepsi inilah yang menjadikan strategi penetapan harga yang tepat menjadi begitu penting.

Dalam bisnis umumnya mempunyai dua strategi antara lain antara lain:

1. Penetapan harga rendah yang memfokuskan kontinuitas pesaing (tidak selalu paling murah)

2. Penetapan harga tinggi atau rendah. Biasanya penjual menawarkan harga tinggi atau rendah berdasarkan kualitas produk yang dihasilkan oleh penjual jika penjual menghasilkan kualitas yang tinggi maka harga yang di tetapkan juga akan tinggi dan sebaliknya ketika kualitas yang dihasilkan itu rendah maka harga yang ditetapkan akan rendah juga.

Selanjutnya kita harus mengetahui sasaran penetapan harga, usaha Kembang Mas harus memiliki tujuan yang akan dicapai, dalam hal ini perusahaan juga harus menentukan sasaran penetapan harga sebelum menetapkan harga itu sendiri. Menurut "Phillip dan Duncan (2016) menjelaskan bahwa sasaran penetapan harga dibagi menjadi tiga yaitu :

1. Berdasarkan dari laba :

- Memperoleh tujuan laba penjualan ataupun laba investasi lebih.

- Memperoleh keuntungan sebanyak-banyaknya.

2. Bedasarkan dari penjualan :

- Meningkatkan penjualan

- Mempertahankan atau meningkatkan pasar

3. Berdasarkan dari status quo :

- Menstabilkan harga

- Menangkal persaingan."

Berdasarkan sasaran penetapan harga di atas, usaha kembang mas lebih mengarah ke orientasi pada status quo karena usaha kembang mas bergerak di industri konveksi yang dimana banyaknya persaingan di industri konveksi membuat konsumen memiliki berbagai alternative untuk memilih harga yang paling murah, maka usaha kembang mas harus berfokus untuk menstabilkan harga agar konsumen merasa bahwa harga yang di berikan itu tidak mahal sehingga konsumen dapat melakukan pembelian ulang atau atau repurcahse.

Setelah mengetahui sasaran penetapan harga maka langkah berikutnya yaitu melakukan penetapan harga menurut Suyanto (2017) ada enam langkah dapat di ikuti oleh perusahaan dalam melakukan penetapan harga jual antara lain: 
1. Memilih sasaran harga

Yang dimaksud dari memilih sasaran harga disini ialah tujuan-tujuan dari perusahaan dalam melakukan penetapan harga. contohnya dalam upaya bertahan hidup perusahaan menurunaan harga jual.

2. Menentukan Permintaan

Di dalam langkah selanjutnya ini perusahaan menentukan permintaan yang nantinya menunjukan jumlah yang akan dibeli pada waktu tertentu dalam tingkat harga yang berbeda.

3. Memperkirakan biaya

Perusahaan harus dapat memperhitungkan biaya di tingkat produksi. Ada dua biaya perusahaan:

- Biaya tetap (Overhead)

Ialah biaya yang tidak bervariasi dengan produksi atau penjualan,misal gaji karyawan, waktu pengerjaan.

- Biaya variabel

Yaitu biaya yang bervariasi langsung pada kualitas produksi, contohnya bahan yang digunakan dalam memproduksi produk tersebut.

4. Menganalisis Pesaing

Dalam langkah ini perusahaan membandingkan harga dan biaya beserta harga yang telah diterapkan sama pesaing.

5. Memilih metode harga

Pada langkah ini perusahaan wajib memutuskan salah satu dari beragam metode harga yang telah ada.

6. Memilih harga akhir

Langkah terakhir ini harga yang sudah dipastikan perusahaan wajib memperhitungkan keuntungan dan resiko yang akan dihadapi oleh reaksi dari konsumen yang menurutnya kurang puas dengan apa yang sudah diberikan sama perusahaan."

Implementasi dari materi strategi harga, telah disampaikan secara daring melalui zoom meeting. Dalam kegiatan tersebut diikuti pemilik usaha kembang Mas konveksi bordir, dan didampingin 3 mahasiswa. Foto kegiatan saat penyampaian materi berhasil didokumentasikan ditunjukkan pada Gambar 2.

Pada akhir kegiatan dilakukan evaluasi melalui tanya jawab dengan mitra. Mitra diminta memberikan pendapat tentang kegiatan yang sudah dilakukan tim PKM. Mitra sangat setuju bahwa kegiatan ini telah mampu meningkatkan pengetahuannya tentang strategi harga yang sebelumnya belum dimiliki mitra secara optimal.

\section{KESIMPULAN}

Menjalankan sebuah usaha tak akan terlepas dari permasalahan harga. Harga memegang peranan yang sangat penting untuk keberlangsungan hidup usaha Kembang Mas, Melalui implementasi strategi harga telah dilakukan dengan cara sosialisasi materi harga dalam bentuk PPT yang meliputi: pengenalan tentang strategi harga, sasaran penetapan harga, dan langkah melakukan penetapan harga jual yang sebaiknya digunakan mitra. Sosialisasi dilakukan secara daring melalui zoom meeting, diikuti oleh pemilik usaha dan 3 mahasiswa yang terlibat dalam tim PKM sebagai host. Mitra bersemangat menerima materi yang disampaikan tim PKM. Selama proses sosialisai berlangsung mitra banyak berdiskusi dan tanya jawab dengan Tim PKM.

Pada akhir kegiatan dilakukan evaluasi, mitra memberikan tanggapan tentang materi kegiatan telah mampu menambah pengetahuan mitra tentang strategi harga secara lebih optimal. Melalui bekal pengetahuan pemilik usaha kembang Mas menjelaskan akan dapat menghadapi strategi harga dari pesaing. 


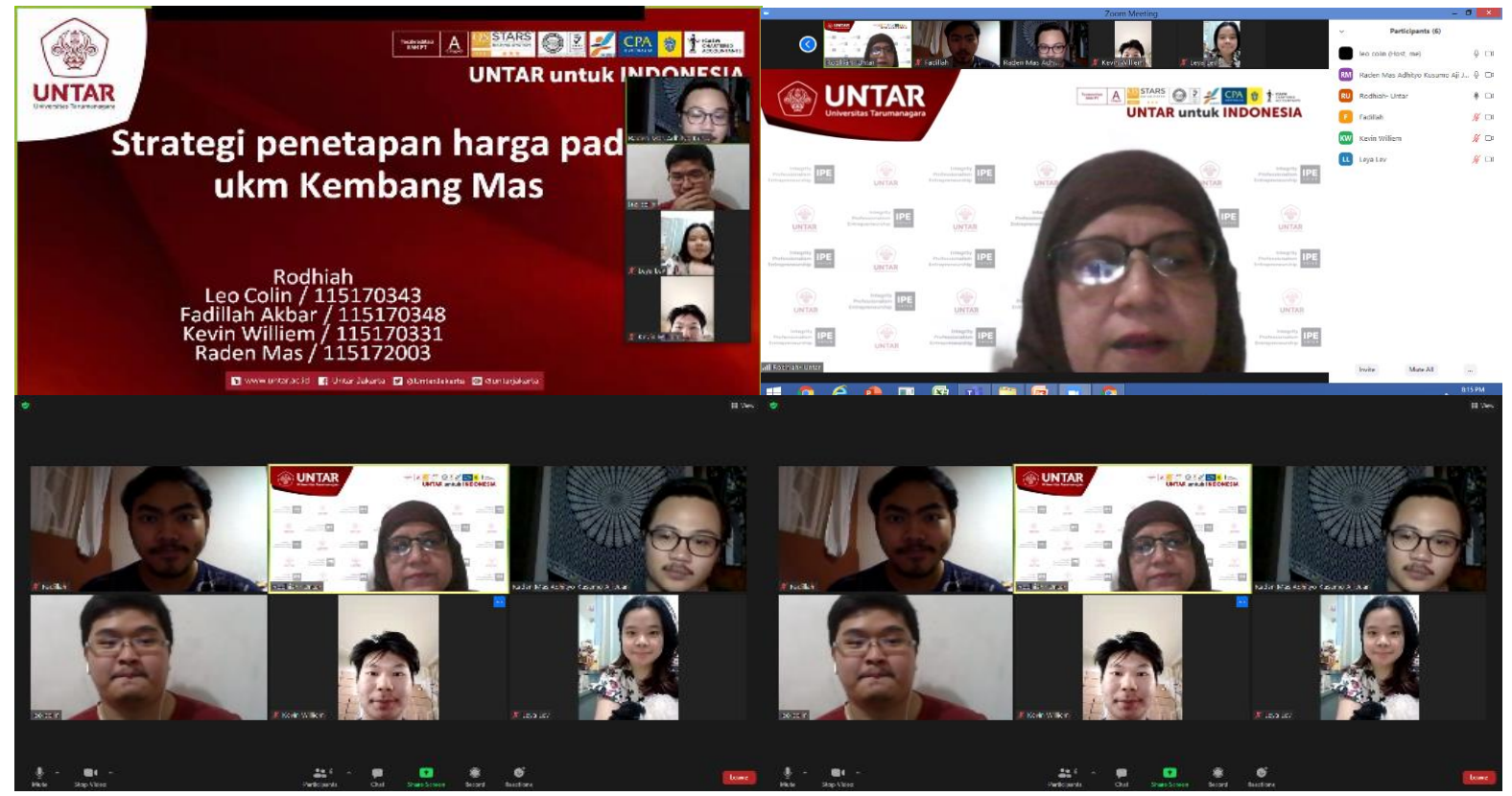

Gambar 2. Foto kegiatan PKM

\section{Ucapan Terima Kasih (Acknowledgement)}

Terima kasih kepada LPPM Untar yang telah memberikan pendanaan pada kegiatan PKM sehingga dapat diselesaikan tepat pada waktunya. Terima kasih juga kepada mitra yaitu Saudari Leva Levina selaku pemilik kembang Mas bordir yang telah bersedia menjadi mitra kegiatan PKM.

\section{REFERENSI}

Afsar. (2019). Effect of Perceived Price, Brand Image, Perceived Quality and Trust on Consumer's Buying Preferences. Journal of Ecoonomics and Business Research, 1, 7-20.

Armstrong, G., \& Kotler, P. (2018). Principle of Marketing Seventeenth Edition. United Kingdom: Pearson Education.

Furinto, Assnan. (2018). "Price or Privilege? Customer Perception on Loyalty Programs". Asean Marketing Journal. 3(2)

Hub Pages. (2013). Role and importance of pricing. Retrieved from: http://hubpages.com/business/Role-and-importance-ofpricing

Kotler, Philip dan Gary Amstrong. (2018). Principles of Marketing. Edisi 15 Global Edition. Pearson.

Meehan, J., Simonetto, M., Montanm L \& Goodin, C. (2011). Pricing and profitability management: A practical guide for business leaders. Singapore: John Wiley \& Sons. Retrieved from:

https://books.google.co.za/books?id=Q5fMZOtlwJMC\&printsec=frontcover\&dq=pricing+mana gement\&hl=en\&sa $=\mathrm{X}$

\&ved=0ahUKEwiR0Lb_vsTLAhWD5BoKHSsYAxsQ6AEINTAB\#v=onepage\&q=prici $\mathrm{ng} \% 20$ management\&f$=$ false

Philip \& Duncan. (2016). Marketing Principles and Methods. Georgetown: Richard D. Irwin. Inc.

Suyanto, M. (2017). Marketing Strategy Top Brand Indonesia. Yogyakarta: Andi Offset.

Witama, Alex (2019). The impact of Brand image, Percived price and Service Quality Toward

Customer Satisfaction. Journal of Marketing. Vol 439. pp 4856-4882 